\title{
The turning period in China's economic development: a conceptual framework and new empirical evidence
}



Ross Garnaut

China began its era of market reform and sustained strong growth in 1978 as a labour-surplus economy. The rapid growth of the modern industrial economy could be supplied with all of the unskilled labour that it wanted to use at a more or less steady real wage. This supported the familiar characteristics of China's economic development in the later reform period: rapid expansion of exports of relatively labour-intensive goods; rising ratios of savings and investment to gross domestic product (GDP); eventually a tendency towards surplus in trade and current external payments; and increasing inequality of income distribution.

There is now compelling evidence that the period of labour surplus and reasonably steady real wages for unskilled workers - supported by continuing large-scale movement of people from agriculture to industry and from the countryside to the cities - has come to an end. The implications of this change for all aspects of Chinese development will be profound. This chapter explores those implications and reviews some of the recent evidence of the imminence of the structural transformation.

Four years ago, the China Update book carried the title The Turning Point in China's Economic Development (Garnaut and Song 2006). This volume began an intense discussion of the idea that China was at or close to the important transition point from a labour-surplus to a labour-scarce economy (Garnaut 2006; Garnaut and Huang 2006; Cai and Wang 2006; Garnaut and Song 2006:Chs 1, 2, 9). Important contributors to that discussion were brought together in a workshop in Beijing in April 2010, organised by the China Center for Economic Research at Peking University and the Institute of Population and Labour Economics at the Chinese Academy of Social Sciences. Selected and edited papers from this workshop are being published in a special issue of the China Economic Journal in 2010. Cai and Wang (in this volume) suggest a precise date-2004-for the turning point. 
Chapter 2 in the 2006 volume by Garnaut and Huang (2006), including the macroeconomic survey of the Chinese economy, summarised the accumulating evidence of labour shortages in parts of the country and accelerating rates of wage increases. It touched on West Indian economist Arthur Lewis's theory of the labour-surplus economy that introduced the idea of the turning point in economic development. It presented some demographic and labour-market projections, suggesting that the Chinese economy by 2020 would be structurally transformed by the combination of rapidly growing demand for and diminishing supply of relatively unskilled labour.

Cai Fang and Dewen Wang in Chapter 9 of that volume noted that China's entry into membership of the World Trade Organisation (WTO) in 2001-far from increasing problems of unemployment, as many had feared-contributed to an acceleration of internationally oriented growth. The continued strength of growth in demand for urban labour and China's emerging demographic transition were leading to the emergence of 'a shortage of rural migrant workers [that] signals, to a certain extent, the transition in the rural labour supply from an unlimited to a limited surplus' (Cai and Wang 2006:143).

The notion that labour shortages and rising real wages would soon play central roles in Chinese development was pushed into the background when the recessionary impact of the great crash of 2008 came to China. In late 2008 and early 2009, there was a large and sharp reduction in demand for Chinese exports and an associated decline of demand for labour in China's coastal cities (Garnaut with Llewellyn-Smith 2009, especially Chapter 9).

Although severe, the labour-market reversal in the global financial crisis turned out to be brief. Shortages of unskilled labour and rising real wages returned quickly, with the extraordinary strength of the Chinese economy's response to the expansionary monetary and fiscal policies that were introduced in late 2008 (Du and Wang forthcoming).

So it is time to focus again on the turning point in Chinese economic development.

This chapter provides a conceptual framework for looking at the impact of the turning point in China and examines the empirical evidence of current and prospective tendencies. The conceptual material reproduces the main content of a paper that will be published in the special issue on the turning point in the China Economic Journal (Garnaut forthcoming). The empirical content of the chapter updates Garnaut and Huang (2006) and Cai and Wang (2006) by drawing on and citing mainly other papers in that special issue of the China Economic Journal. 


\section{The surplus-labour economy}

The idea of the 'turning point' comes from a highly stylised model of economic development in a labour-surplus economy, first developed by Arthur Lewis (1954). The model was elaborated on and applied to an East Asian context by Fei and Ranis (1964a, 1964b, 1966; Ranis and Fei 1961, 1963). It was embedded in Minami's $(1973,1986)$ influential books on Japanese economic development.

The labour-surplus economy of the model is dualistic, with a highly productive and dynamic 'modern', 'urban', 'industrial' or 'capitalist' sector and a relatively unproductive and stagnant 'traditional', 'rural' or 'village' sector. In the stylised labour-surplus economy of the model, the marginal product of labour in rural areas is well below the living standards that poor residents of rural areas enjoy. (In some versions of the model, the marginal product of rural labour is zero or even negative in the early stages of modern economic growth.)

Living standards in rural areas can remain above the marginal product of labour because they are supported by village institutions, which leads to some sharing of incomes and employment. There are risks and costs of moving from the rural sector to the urban sector for employment. Assessments of these costs and risks, on top of the customary rural standard of living, establish the 'reserve price' of labour - or the urban wage at which migrants are prepared to migrate. It follows that the marginal product of labour in urban areas is strongly positive.

When a worker moves from rural to urban employment, the total output of the economy rises: there is an increase in urban output, but no or little reduction in rural production. Rural-urban migration is a main source of growth in average productivity and total output. As a matter of arithmetic, average output rises in rural areas with migration (with the same output and less people). In the early stages of expansion of the modern economy, however, and perhaps for a considerable while, there is still redundant rural labour and the marginal product of labour in rural areas remains low or zero. The reserve price of rural labour remains low and for a while is unresponsive to increased urban demand for labour.

The availability of an 'infinitely elastic' supply of labour from rural areas has important implications for the structure of growth in the urban and rural economies.

Rapid expansion can proceed in the urban sector without increases in real wages. The improvements in infrastructure, labour culture and management practices that raise productivity with the passing of time are reflected in a rising rate of 
return on investment and an increasing profit share of modern-sector income. The rising modern-sector share of the economy contributes to a rising profit share in the economy as a whole.

Savings are a much higher share of profits than of wages, so that a rising profit share of income is associated with a higher savings share for the economy as a whole. The higher savings, in turn, support higher levels of investment in the usual situation of home-country bias in investment, with home investment further encouraged by the high and rising rates of return on investment.

A falling consumption share is the other side of the coin to a rising savings share. Also as a matter of arithmetic - although not mentioned in the early theoretical treatments of the subject - and highly relevant to recent Chinese reality, an increasing excess of savings over investment causes the rate of growth of output to be unnecessarily low. In the labour-surplus economy, this does not lead to increasing unemployment of domestic resources. Rather, it leads to economic growth rates that are unnecessarily low, which therefore cause unnecessary delays in the absorption of underemployed labour in the village economy into the modern sector.

On the other hand, if the high and rising returns to investment in the modern sector cause the investment share to rise more rapidly than the savings share, there will be a tendency towards deficits in external trade and current payments. The same outcome will follow if the public sector's claims on resources expand more rapidly than is necessary to absorb any surplus private-sector savings. Such external current payments deficits are sustainable only if the country has ample access to international markets for capital on favourable terms. Where they are sustainable, their presence is likely to raise the sustainable rate of growth and the rate at which underemployed labour in the countryside is absorbed into modern and economically productive activity.

With rising returns on investment and a rising profit and therefore savings share of income, it can be expected that the rate of investment will rise over time. The combination of rising investment rates and the increasing share of the expanding modern sector in the economy is likely to cause the rate of growth in output to accelerate over time.

In the rural sector, the marginal product of labour remains well below the customary minimum income level. Expansion of the modern sector and migration from the village introduce no pressure to economise on the use of labour in production. Average standards of living rise in the village, without noticeably affecting the customary income levels of the low-income workers who are available for emigration to the modern sector. 
In the labour-surplus economy, comparative advantage in international trade is initially in small volumes of commodity exports, before the emergence of a dynamic modern sector. Modern economic growth and the development of the urban economy see comparative advantage in international trade shift to labour-intensive manufactured products; these contribute most of the growth in exports as the modern sector expands and the proportion of exports from the modern sector rises over time. The rapid accumulation of capital in the modern sector, combined with the labour force's learning of industrial disciplines and techniques, makes production of a wider range of traded goods and services profitable in the modern sector. This causes comparative advantage to emerge in some more sophisticated manufactured products, without any weakening of competitiveness in the production of labour-intensive traded goods. At this stage there is no pressure for absolute contraction of labour-intensive industries in the traded-goods sector.

In the labour-surplus economy, the fall over time in the wage share of income is associated with a widening of inequality in the distribution of income. The faster the rates of growth in investment and output, the faster will be the rate of increase in inequality. The faster the rate of growth, however, the greater will be the rate of emigration from rural to urban areas, the quicker will be the absorption of the surplus rural labour into productive modern-sector employment and the earlier will be the turning point from an economy in which labour is in surplus to one in which labour is scarce.

\section{The turning point}

If the rate of economic expansion in the modern sector is fast enough for the rate of emigration from the villages to exceed the natural increase of the rural population that is of working age, sooner or later, there will be no surplus of labour in the rural economy. At this point, any further emigration raises the marginal productivity of labour in rural employment above the rural wage. The real wage rate increases in the rural and urban sectors. This is the 'turning point in economic development'.

From the turning point, the wage share of income rises and the profit share falls. The rate of consumption can be expected to rise with the wage share. The rate of consumption in the whole economy rises and the rate of savings falls.

The increase in urban wages is likely to cause the rate of return on investment in labour-intensive production in the modern sector to fall. The combination of lower profitability of investment, and of lower savings accompanied by the usual home bias in investment, is likely to reduce the share of investment. 
All other things being equal, one would expect the rate of growth of output to fall with the share of investment in expenditure. This is not, however, an inevitable accompaniment of the turning point in economic development. There are two circumstances in which there will be no fall in the rate of growth in output. One of these circumstances could arise if, before the turning point, savings fell short of investment, giving rise to a surplus in external trade and current payments. This would be a case in which the rate of growth before the turning point was unnecessarily low and therefore the turning point of economic development was unnecessarily delayed. In this case, the rebalancing of expenditure from investment demand to consumption associated with the rising wage share of income could occur without any reduction in the rate of growth in the capital stock.

The second circumstance in which there might be no reduction in the rate of growth after the turning point would be if the rate of total factor productivity growth increases to balance a reduced rate of investment and reduced rate of increase in the capital stock. There is a reason to expect some increase in productivity growth beyond the turning point. Higher wages are likely to force economisation in the use of labour and to raise productivity growth in the rural and urban sectors.

It follows that the rate of economic growth could be faster, similar to or slower after the turning point than in the labour-surplus economy.

Whatever the impact of the turning point on the rate of economic growth, the tendencies towards decline in the savings rate are likely to be more powerful than the tendencies for decline in the investment rate, leading to a tendency towards smaller surpluses or larger deficits in foreign trade.

Beyond the turning point, there is a reversal of the tendency for economic growth to exacerbate the widening of income inequalities. At last, rural communities and low-skilled urban workers come to share in the fruits of modern economic growth. The faster the rate of growth in investment, productivity and output after the turning point, the more rapid will be the rise in rural standards of living and workers' income levels in rural and urban areas. The faster the rate of growth after the turning point, the more rapid will be the reduction in income inequalities.

The critical contribution of rapid growth before the turning point to the reduction in inequality is its bringing forward in time the point at which labour becomes scarce and labour incomes rise. The critical contribution of rapid growth after the turning point to the reduction in inequality is to accelerate the increase in real wages and rural living standards relative to incomes from ownership of capital. 
The changes in labour's share of income before and after the turning point are one explanation of the 'Kuznets curve' - the observed tendency for modern economic growth to at first exacerbate and to later reduce inequality in the distribution of income, at least for some time beyond the turning point in economic development.

There is no inevitability about the labour-surplus economy reaching the turning point. It will reach this point only if growth in the modern sector is sufficiently rapid and sufficiently labour intensive to absorb labour from the countryside substantially more rapidly than it is augmented by natural increase. If the modern sector of the labour-surplus economy grows too slowly relative to population increase or policy distortions cause growth to be associated with low increases in demand for labour, modern economic growth can be associated with continued steadiness in real wages and ever-increasing dispersion of the distribution of income.

Real wages rise rapidly with continuing economic growth beyond the turning point in economic development. Whether or not this is inflationary depends on the stance of monetary policy. As long as economic growth continues reasonably strongly, the increase in real wages increases domestic costs relative to the prices of internationally traded goods - that is, it increases the real exchange rate. The increase in the real exchange rate occurs no matter how the nominal exchange rate is managed. The conduct of monetary policy in a way that leads to an increase in the foreign exchange value of domestic currency - that is, to nominal exchange rate appreciation - allows the increase in the real exchange rate to occur with lower inflation than would otherwise occur. The avoidance of inflation as economic growth continues beyond the turning point requires firm monetary policy alongside appreciation of the nominal exchange rate.

Here there are risks of errors in economic policy, which, if they materialise, could unnecessarily diminish the rate of economic growth and the rates of increase in real wages and living standards in rural and urban areas. If the authorities become worried about inflation while wanting to avoid an appreciation of the nominal exchange rate (perhaps in an attempt to protect the labour-intensive industries whose competitiveness is declining), they could seek to tighten expenditure policy in an attempt to hold inflation to low levels. This generates a tendency to surplus in external trade and payments. For a while, this reduces the rate of growth below sustainable levels. The payments surplus generates tendencies to monetary expansion and to the re-emergence of inflationary pressure. In the end, it is likely that the rate of growth will tend towards sustainable levels, with the real appreciation being achieved after a lag through inflation.

Any protection of old, labour-intensive industries that comes with avoidance of appreciation in the foreign exchange value of domestic currency turns out 
to be temporary. The temporary respite comes with potentially large costs: the economy will experience unnecessary inflation and needlessly forgo some increase in economic output, real wages and living standards. In the worst case, the inflation will destabilise aspects of political as well as economic life and indirectly lead to larger losses in economic growth and potential increases in living standards.

Comparative advantage in foreign trade after the turning point shifts out of labour-intensive products into more capital-intensive and technologically more sophisticated goods and services. These more technologically complex products require higher-quality inputs of human resources (education and training) and infrastructure for communications, finance and regulatory arrangements. These requirements make heavy demands on the quality of various services provided by government. Weaknesses in these areas are more likely to emerge as bottlenecks to the continuation of rapid economic growth after rather than before the turning point in economic development.

\section{Real-world variations of the stylised surplus- labour model}

Like any model, the Lewis model of the labour-surplus economy embodies simplifications of reality. Some of these simplifications materially affect its application to analysis of contemporary Chinese economic development. This section examines some of the most important departures of the real from the stylised economy when the model is applied to China's economic development.

The most important departure of reality from the model is in the geographically differentiated nature of the labour market in the huge Chinese economy. Within China, there is imperfect mobility of labour among provinces and regions and differentiated barriers to movement between various rural areas and cities. Imperfect mobility and differentiated barriers are reflected in differing wage levels and material standards of living across the various parts of the country. As a consequence, as urban demand for labour grows, labour could be drawn disproportionately for a while from one source while being drawn less intensively from others. One part of the rural economy could find that its surplus labour has been absorbed fully into the modern economy and that the real wages demanded by potential immigrants from that rural region begin to rise strongly, while there is surplus labour and availability of labour at 'traditional' wages elsewhere. Relatively low-skilled labour could become relatively scarce and real wages could rise in some cities, while it is available at lower costs in others. 
The main consequence of China's geographically differentiated labour market is that there is a 'turning period' during which real wages begin to rise strongly, rather than a 'turning point'. Real wages rise rapidly in some cities, forcing a reduction in the profit share of income, increases in consumption and structural change out of simple, labour-intensive products and techniques, while lower wages persist and labour-intensive production continues to prosper and expand elsewhere. Similarly in the rural economy, labour becomes relatively scarce, living standards rise rapidly and production shifts out of labour-intensive activities in some villages while labour remains abundant in others.

The surplus-labour model's second major departure from reality is the assumption that there is a stable conventional standard of living for potential migrants among rural residents until there has been sufficient emigration to raise the marginal product of rural labour above that standard. Even in the early stages of emigration from part of the rural economy, higher average material living standards and consumption are likely to be reflected in some enhancement of the living conditions of potential emigrants. As a result, the reserve price of rural labour - and therefore the wages of urban workers - rises to some extent from an early stage in modern economic development. Entry into the turning period will be marked by an acceleration of wage increases, rather than by a sharp movement from stable to rapidly increasing real wages.

The third major departure is that in reality, but not in the model, labour is highly differentiated by skills, resulting from differences in education, training and experience in the modern economy. The model focuses on relatively unskilled labour, the availability of which is diminished by increases in education, training and experience. Changes in these factors influence the arrival and duration of the turning period during which relatively unskilled labour becomes scarce and its wages rise. In particular, the high and on average rapidly rising investment in education per student and the accumulation of skills through experience in the modern sector of the economy are reducing the stocks of low-skilled labour available to the urban economy. This has been bringing forward the turning period in China's economic development. In combination with the demographic crunch following from the sharp decline in fertility in the 1970s and 1980s, these factors will cause the rate of increase in real wages during and beyond the turning period to be much sharper than in other labour-surplus economies that have moved through and beyond the turning point.

The fourth major departure is that the real economy does not contain only 'traditional' and 'modern' sectors. There is also a government sector that provides services and modifies demand and supply for various types of labour, and affects living standards in rural and urban areas. The government sector supplies inputs that are critical to economic growth. The government sector's command over resources and also its role in providing essential inputs for development 
are likely to be relatively small in the early stages of development of a laboursurplus economy. The government's potential command over resources expands with the modern sector and its role in continued rapid growth becomes more important over time.

The main effect of the first two departures of reality from the model is to transform the turning point into a turning period.

The main effect of the third departure is to bring forward in time the turning period and to shorten its length.

The effects of the fourth departure are manifold. Improvements in government services in rural areas can raise the reserve price of emigrant labour and therefore the urban wage for unskilled labour. Provision of education services can reduce the pool of surplus labour and bring forward the turning point. Public-sector demand for labour augments demand from the modern industrial sector and brings forward the turning point.

Government policy can affect population growth and, over time, the amount of unskilled labour in the countryside. It can affect the labour intensity of modernsector economic growth. The effectiveness of government provision of various inputs into the development process affects the rate of growth even before the turning period. Its effects are, however, larger during and after the turning period, as growth comes to make larger demands on infrastructure, education and skills, financial services and the sound regulation of private economic activity.

\section{The 2006 evidence of China entering the turning period}

Garnaut and Huang (2006) went through a number of factors influencing the turning point in China's economic development and concluded in a preliminary way that it was not far away. The anecdotal evidence of shortages of labour in some areas and large recent increases in real wages started to make the point. The looming demographic transition deriving from the large and sudden decline in fertility a generation ago, the strength of modern-sector economic growth, the improvement in rural education, including for girls, and the evidence of labour shortages in some rural as well as urban areas all pointed to the imminent arrival of the turning point.

We observed that in the early years of Chinese economic reform after 1978, the large underemployment in the agricultural sector and potential productivity gain from transferring workers from rural to urban employment created the 
conditions for economic growth within the labour-surplus economy. For a couple of decades after the start of reform, real wages of migrant workers had been fairly stable while large numbers of rural residents entered industrial employment. We noted that the reports of shortages of migrant labour seemed odd, given that the standard accounts suggested that there were still 300 million agricultural workers - well above the requirements of agricultural production, even with established agricultural technologies. There were several reasons why the shortages could have reflected temporary influences, rather than the major structural factors that would be associated with China having passed the turning point in economic development. Rising food prices and various government measures to improve rural living conditions had raised the supply price of migrant labour. The absence of an efficient and informed labour market allowed regional shortages to appear even if there was no national shortage. Employers in the cities were seeking to raise productivity and seeking to recruit workers with two to three years' experience, so some reports of labour shortage might not have related to unskilled labour straight from villages. Not all workers from the village were in similarly strong demand: females aged between eighteen and twenty-five were especially valued, and the total pool of about 70 million people in this category was running dry.

Nevertheless, the anecdotal evidence was considerable and was backed up by some relevant statistical data. Migrant workers' cash wages had increased by 20-40 per cent in 2004. Labour fringe benefits were increasing rapidly in scope and size as employers sought to make their employment offers more attractive.

We noted that eventually rising labour costs were a normal phenomenon with successful development of a labour-surplus economy. China's real manufacturing wages in US dollars in 2006 were about 5.6 per cent of those in the United States. Korea's had been a bit below that proportion at 5.2 per cent in 1975, but 29 years later were 49.7 per cent of those in the United States. We asked: will it take more or fewer years for China's labour costs to rise to half of those in the United States?

China's nominal wages had fluctuated with inflation for more than two decades of the reform period with only small increases in real wages. Real wage growth had lifted sharply from about the turn of the century and had remained in double digits from that time. Wage growth had been even more rapid in the less-advanced regions than in the established industrial cities, Guangdong and Shanghai. Until 2003, real wages grew less strongly than average productivity, but in 2004 and 2005 wages growth ran ahead of productivity. This had been reflected in a sharp increase in the share of employee earnings in total industrial value added from the last quarter of 2004 and through 2005, reversing many years of decline. 
These generalisations were based on general wage data, mixing skilled and unskilled elements. A look at the forward-looking data for unskilled labour pointed to a likely special tightening of the market for unskilled migrant labour. China's rapid demographic transformation following the rapid decline in fertility in the late 1970s and 1980s meant that the total labour force was now hardly growing at all, and any significant migration out of the villages caused the rural labour force to decline. These tendencies would strengthen over time. The general decline in the labour force would be especially sharp for unskilled workers, as increasing public investment in education applied to a falling number of children was increasing the proportion of new members of the labour force whose education removed them from the pool of 'unskilled' labour. We noted that all successful labour-surplus economies had passed through a labour-market turning point, with immense implications for the structure of the economy and its relations with the rest of the world. We commented that China would not be an exception, and its time was coming soon.

Cai and Wang (2006) analysed developments in demand and supply for migrant labour, demonstrating that both had contributed strongly to the rapid depletion of surplus labour in the Chinese countryside since the turn of the century.

On the demand side, China's entry into the WTO in 2001 and the accelerated domestic trade liberalisation with which it was associated had lifted growth rates and had also made the pattern of modern-sector growth more labour intensive in line with China's comparative advantage in international trade. Thus, demand for unskilled labour had grown strongly through the early twenty-first century, despite the shedding of large amounts of labour through state-owned enterprise (SOE) reform.

On the supply side, China had entered a period of dramatic contraction of the unskilled labour force. The working-age population would reach a peak in 2016 and then fall steadily. The numbers of younger elements of the labour forcethose available for rural-urban migration - would begin to decline earlier and the proportion of that group available for unskilled work would fall rapidly with expansion and improvement of the quality of education.

Cai and Wang thought that China had reached the turning point.

\section{The evidence in $\mathbf{2 0 1 0}$}

The chapters in The Turning Point in China's Economic Development in 2006 were noting early and partial evidence of China's entry into the turning period. Data and analysis presented in the special issue of the China Economic Journal 
suggest that the Chinese economy has now moved more decisively and deeply into the turning period (Du and Wang forthcoming; Cai and Wang, this volume; Cai forthcoming; Garnaut forthcoming).

The impact of the global financial crisis on China complicates the interpretation of the evidence between 2006 and 2010, but only slightly. The effects of the crisis were quickly overwhelmed by the longer-run tendency for tightening of the labour market. The global financial crisis led to a sharp reduction in demand for labour in the export-oriented coastal cities in late 2008 and early 2009. For a while, the greatest migration in human history went into reverse, as redundant workers returned to the countryside. When retrenched workers returned to work in 2009, there were reports of downward revision of terms of employment.

The Chinese Government responded to the recessionary impact of the global financial crisis by launching the world's greatest exercise in Keynesian expansionary policy, to counteract the effects of global recession (Garnaut with Llewellyn-Smith 2009). The success of the expansionary policies meant that by the middle of 2009, the flow of migrants from rural to urban areas had been restored and then increased beyond pre-crisis levels, hastening movement into and through the turning period in China's economic development.

It is the combined effects of these two developments that we see in the Chinese labour market through 2009 and 2010.

Du and Wang (forthcoming) undertake sophisticated analysis of Chinese labourmarket data in reaching strong conclusions that real wages of unskilled workers have been rising strongly through the early twenty-first century after a couple of decades of relative stagnation, and that the momentum of real wages growth was quickly restored after the shock of the financial crisis. The pre-crisis momentum of growth in real wages of low-skilled migrant workers was so strong that there was an increase of 20 per cent for 2008, which ended in the midst of labourmarket retrenchment. Momentum was briefly lost, but was resumed in time for real wage growth to again be positive for 2009. Real hourly wages for migrant workers increased by 90 per cent from 2001 to 2009 and by 77 per cent from 2003 to 2008 (Du and Wang forthcoming). Non-wage benefits increased more rapidly than wages.

Looking forward, they note that assessments based on the continuing presence of 300 million agricultural workers are misleading. A high proportion of those workers have substantial non-agricultural income; for many, non-farm income is dominant. The economic censuses in 2004 and 2008 show growth of more than 30 million in secondary and more than 50 million in tertiary employment over the four years. Application of employment elasticities of growth to plausible rates of expansion of the secondary and tertiary sectors suggests employment 
increases of about 24 million per annum in the years immediately ahead - if the elasticities or growth are constrained by neither labour shortages nor rising real wages.

Will labour-market realities allow such strong employment growth? The average annual increase in the working-age population is expected to fall from about seven million per annum in 2006-10 to about 3.1 million per annum in 2011-15, and then to decline absolutely by about one million per annum in 2016-20 and five million per annum in 2021-25. The rapidly increasing investment per student in education means that the emerging labour-market squeeze is tightest for low-skilled labour. The focus of government policy in recent years on raising incomes and services in rural areas, along with the rapid expansion of off-farm rural incomes and the absorption in the past of a high proportion of young rural workers - those who are most likely to seek urban employment - further constrain the increased supply of migrant labour.

Du and Wang's analysis draws attention to powerful tendencies to acceleration of real wages growth for labour in general and low-skilled workers in particular.

Cai Fang (forthcoming) raises questions about the bases of the Chinese demographic data and the answers all suggest risks of even greater labourmarket tightening in the period ahead. The periodic survey of agricultural costs suggests that the remaining agricultural labour potentially available for migration to urban employment is less numerous than presumed in any of the widely used studies. As a result, the marginal product of rural labour - and therefore its supply price - is much higher than generally presumed, and rising.

The differences in data from the household survey and the urban unit reporting system suggest that there are 95 million more migrant workers in urban areas than is commonly presumed.

Analysis of the 2000 census and 2005 sample census data suggests that national fertility rates have fallen below those applied to the standard population projections.

The weight of the evidence points to a reasonable expectation of rapidly rising real wages - and more rapidly for low-skilled workers - as the only means of bringing runaway growth in demand for labour back in line with labour's availability. 


\section{Implications of the turning period for Chinese development}

What are the implications of the turning period for China's continuing economic development, for China's interaction with the global economy and for economic policy? I will focus on four of the most important consequences, mention a consequence that is widely anticipated and feared, but which need not eventuate, and briefly discuss one way in which perceptions of China's growth will be affected by its having entered the turning period.

As China enters deeply into the turning period, there will be large and continuing increases in real wages and in the wage share of income. The powerful tendency since the 1980s towards increased inequality in income distribution is likely to be reversed. This is one important consequence. The rise in the wage share of income is likely to be reflected in an increase in the consumption share of expenditure. There will be a reduction in the national savings rate.

It is possible that, at least for a while, the investment rate will in fact rise. Whether or not this is the case, it is likely that China's savings rate will fall more than its investment rate. This will reduce the external surplus in trade and current payments. It will therefore ease current international pressures over payments imbalances and exchange rates. It would be wise for China to ensure that total domestic demand - the sum of demand from private and public investment and consumption - expands enough to ensure that this is the case.

The reduction in Chinese current external payments surpluses is therefore a second important consequence of moving through the turning period. This could ease tensions with other countries - especially the United States - which have identified Chinese surpluses as a principal cause of their own economic problems. Regrettably, the reduction of Chinese surpluses will not help the reality of other countries' economic problems as much as perceptions of them. Indeed, a large fall in Chinese current savings relative to investment would put upward pressure on global long-term interest rates and increase the requirement to reduce domestic expenditure on goods and services in the countries facing large challenges in the management of external and public debt, including the United States. This will make economic management problems in those countries more difficult, not easier.

The third important consequence of China moving through and beyond the turning period is that the centre of China's comparative advantage in international trade will shift rapidly from a fairly narrow range of labour-intensive products to a wider range of more capital-intensive and technologically sophisticated products. This will ease some dimensions of China's trade problems with the rest of the world (perceptions of competitive pressure on other developing countries 
and heavily concentrated pressures for adjustment on particular sectors in industrialised countries) and complicate others (competitive pressures will be felt across a much wider range of industries in industrialised countries). The diversification of China's comparative advantage will probably halt the decline in Chinese export prices that was associated with the heavy concentration of export expansion in a small number of products.

The fourth important consequence of entering the turning period involves a policy risk to economic stability and growth in the period ahead. Rising real wages and the pressure of strong increases in demand for non-traded goods and services will be inflationary unless accompanied by a combination of firm monetary policy and an appreciating renminbi. Nevertheless, the Chinese authorities might be tempted to maintain the fixed exchange rate against the US dollar to avoid adjustment pressures on export-oriented labour-intensive industries, which have played such an important part in Chinese economic growth since the mid 1980s.

To seek to maintain a fixed exchange rate against the US dollar through and beyond the turning period would only postpone and not avoid the structural adjustments that are a necessary accompaniment of the current stage of Chinese economic growth. Payments surpluses would eventually overwhelm the efforts to sterilise their monetary effects. The adjustments would occur through inflation.

It is likely that the authorities would respond to higher inflation by tightening fiscal and monetary policies. This would unnecessarily reduce the rate of economic growth below sustainable levels and postpone the increase in Chinese living standards that can come through and beyond the turning period. The inflation and the delays in inequality reductions could be destabilising to domestic political stability. The delays in reduction in the external payments surplus would certainly be destabilising for China's productive interaction with the international economy and society.

I conclude by pointing to one consequence of moving through and beyond the turning period that is often feared but which is unlikely to be important unless there are mistakes in economic policy, and to one important implication for perceptions of the growth of the Chinese economy.

There is no basis for the expectation that China's rate of growth in output per worker must necessarily fall as it moves through and beyond the turning period. The rise in real wages as China moves through the turning period is likely to lead to an increase in the rate of total factor productivity growth. In the nature of things, this will be concentrated in industries producing relatively sophisticated and capital-intensive products, the competitiveness of which 
is less sensitive to increases in real wages. It is possible that the increase in Chinese domestic demand that is necessary to reduce external current payments surpluses will require an increase in the investment rate for a while. Together with the expected acceleration of productivity growth, this would support an increase in the growth rate in total output per worker, above the high rates of the early twenty-first century. That will surprise the world and also the Chinese authorities, but it might be necessary to maintain internal and external balance in the period ahead.

How successful China is economically in this period of rapidly rising real wages will depend on the flexibility of the economy, its openness to foreign trade and investment and the world's most productive ideas about managing enterprises, the quality of the human resources created by the rapid expansion of the education system in the past couple of decades and the quality of the regulatory systems applied to the more complex economy that is emerging. It is possible that the rate of growth in total output can be maintained at something like the average rates of the decades of reform, until the approach of the industrialised countries' frontiers of productivity and living standards reduces the scope of rapid productivity growth through 'catching up' with the industrialised countries.

Whether or not China succeeds in maintaining such high aggregate rates of growth until it reaches the frontiers of the world economy, most observers will be surprised by how quickly China catches up now that it has entered the turning period. China's real exchange rate will rise rapidly — whether that occurs through inflation, nominal exchange rate appreciation or a combination of the two. The value of China's output when measured in the national accounts and converted into international currency at current exchange rates will converge towards the much higher 'purchasing power' estimates of GDP. People in China and abroad who focus on conventional measures of national output will find that China catches up with the world's most productive economies in output per person - and with the United States in total output - much more quickly than they had been expecting from extrapolation of differentials in national growth rates.

\section{References}

Cai, F. (forthcoming), 'Demographic transition, demographic dividend, and Lewis turning point in China', China Economic Journal, Special Edition. 
Cai, F. and Wang, D. 2006, 'Employment growth, labour scarcity and the nature of China's trade expansion', in R. Garnaut and L. Song (eds), The Turning Point in China's Economic Development, Asia Pacific Press, Canberra, pp. 143-71.

$\mathrm{Du}$, Y. and Wang, M. (forthcoming), 'A discussion on potential bias and implications of Lewisian turning point', China Economic Journal, Special Edition.

Fei, J. C. H and Ranis, G. 1964a, Development of the Labor Surplus Economy: Theory and policy, Richard D. Irwin, Homewood, Ill.

Fei, J. C. H and Ranis, G. 1964b, 'Development of the labor surplus economy: theory and policy', Economic Development and Cultural Change, vol. 41, pp. 147-74.

Fei, J. C. H. and Ranis, G. 1966, 'Agrarianism, dualism and economic development', in I. Adelman and E. Thorbecke (eds), Theory and Design of Economic Development, Johns Hopkins University Press, Baltimore.

Garnaut, R. 2006, 'The turning point in China's economic development', in R. Garnaut and L. Song (eds), The Turning Point in China's Economic Development, Asia Pacific Press, Canberra, pp. 1-11.

Garnaut, R. (forthcoming), 'Macro-economic implications of the turning point', China Economic Journal, Special Edition.

Garnaut, R. and Huang, Y. 2006, 'Continued rapid growth and the turning point in China's economic development', in R. Garnaut and L. Song (eds), The Turning Point in China's Economic Development, Asia Pacific Press, Canberra, pp. 12-34.

Garnaut, R. and Song, L. (eds), 2006, The Turning Point in China's Economic Development, Asia Pacific Press, Canberra.

Garnaut, R. with Llewellyn-Smith, D. 2009, The Great Crash of 2008, Melbourne University Publishing, [Chinese translation published by China Academic Press, Beijing].

Lewis, W. A. 1954, 'Economic development with unlimited supplies of labour', Manchester School of Economic and Social Studies, vol. XXII (May), pp. 139-91.

Minami, R. 1973, The Turning Point in Economic Development: Japan's experience, Kinokuniya Bookstore, Tokyo. 
Minami, R. 1986, The Economic Development of Japan: A quantitative study, Macmillan, London.

Ranis, G. and Fei, J. C. H. 1961, 'A theory of economic development', The American Economic Review, vol. 51, no. 4, pp. 533-65.

Ranis, G. and Fei, J. C. H. 1963, 'The Ranis-Fei model of economic development: reply', The American Economic Review, vol. 53, no. 3, pp. 452-4.

\section{Acknowledgments}

The conceptual core of this chapter is drawn from a forthcoming (2010) paper in the China Economic Journal: 'Macro-economic implications of the turning point.' The author is grateful to the editors of the journal for agreeing to its publication in this form. 